\title{
AIDS TO NAVIGATION SYSTEMS ON INLAND WATERWAYS AS AN ELEMENT OF COMPETITIVENESS IN ULCV TRAFFIC
}

\author{
Septimio Andrés ${ }^{1}$, Francisco Piniella ${ }^{2}$ \\ ${ }^{1}$ AtoN Service, Port of Seville, Spain \\ ${ }^{2}$ Department of Maritime Studies, University of Cádiz, Spain
}

Received 17 November 2016; accepted 31 January 2017

\begin{abstract}
The container has been a key driver of globalization. With the passage of time, this has led to build larger container ships. The principal issue is the adaptation carried out by main ports to become ports of call of these Ultra Large Container Vessel (ULCV). These modifications are irrelevant for seaports with enough depth, but much more complex for "inside seaports" due to the required approach channel update. Scarce ports that are receiving ULCV, most of which are seaports, are making a select "hub club". This paper analyses how Aids to Navigation systems can help inside seaports to become port of call of ULCV, allowing them to maintain its competitiveness. For this purpose we will focus on the cases of ports of Hamburg and Antwerp, and we will also analyse if the general trend of ULCV dimensions were growing, would allow it to maintain its international maritime traffic role.
\end{abstract}

Keywords: AtoN, navigable rivers, ULCV, container traffic, competitiveness.

\section{Introduction}

As economies and borders have opened to international trade, the main maritime transport structures have witnessed a steady process of deregulation (Alderton et al., 2002; Silos et al., 2012). Simultaneously, technological innovations in transport have facilitated the movement of large volumes of goods at ever-decreasing costs and with increasing reliability (Vivas, 1999). In particular, container ships have proved to be a key element of globalisation, forming the unitised basis of international transactions.

Ports are experiencing increasing competition, as efforts are made to reduce costs and a ship's length of stay in port. (González, 2007) has identified three main trends in shipping:
1. The use of container ships. In just twenty years, container ships have grown from less than two million TEU (container ship capacity is measured in twenty foot equivalent units) to fifteen million TEU.

2. Corporate concentration through mergers and alliances, which reduces costs and improves competitive positioning. Shipping companies form part of much larger business conglomerates: $2 \mathrm{M}$ (Maersk Line and MSC), O3 (CMA CGM, CSCL and UASC), CKYHE (Cosco, K-Line, Yang Ming, Hanjin and Evergreen) and G6 (MOL, Hapag Lloyd, OOCL, HMM, NYK and APL) (Muñoz, 2014).

3. The emergence of port hierarchies, whereby ports are controlled by port operators, and linked to their

${ }^{2}$ Corresponding author: francisco.piniella@uca.es 
hinterlands, or areas of influence. This has facilitated the formation of hubs, ports where numerous transhipments take place, complemented by feeder services that transport the goods to other areas of consumption in smaller ships.

This article focuses on the new generation of increasingly larger container ships known as ultra large container vessels (ULCV). Their builders guarantee efficiency on three fronts: energy (reducing $\mathrm{CO}_{2}$ emissions by half), economy (generating economies of scale) and the environment (fewer atmospheric emissions). As a result, the shipping company Maersk has named their ULCV the Triple E class. These specialise in the route that passes through the Suez Canal, linking maritime hubs in Northern Europe, the Mediterranean and Asia (Maersk, 2015).
According to Lloyd's Register and Ocean Shipping Consultants (Tozer and Penfold, 2001), ULCV dimensions are as follows: length; $380 \mathrm{~m}$, beam; $57 \mathrm{~m}$, depth; $29 \mathrm{~m}$, and a draught of more than $14 \mathrm{~m}$. This prevents them from using the Panama Canal but does allow them to pass through the Suez Canal. Ships that can sail through the Panama Canal are known as Panamax vessels, and their maximum dimensions, determined by those of the locks they must transit, are: length; $294.1 \mathrm{~m}$, beam; $32.3 \mathrm{~m}$ and draught; $12 \mathrm{~m}$ (up to 5,000 TEU). Expansion of the Panama Canal will allow the passage of Post-Panamax ships (up to 13,000 TEU), measuring $366 \mathrm{~m}$ long with a beam of $49 \mathrm{~m}$ and a draught of $15 \mathrm{~m}$ (Canal de Panama 2015). In contrast, the Suez Canal has no locks and allows the transit of all container ships worldwide, since there are restrictions on length and vessels with a beam of $77 \mathrm{~m}$ and a draught of $20 \mathrm{~m}$ can pass through (Suez Canal Authority 2015) (Table 1).

Table 1

Comparison Between the Ships Dimensions of the ULCV and Panama and Suez Canals

\begin{tabular}{|l|l|l|l|}
\hline Dimensions & Length $(\mathrm{m})$ & Beam $(\mathrm{m})$ & Draft $(\mathrm{m})$ \\
\hline ULCV & $380-400$ & $57-59$ & $14-16$ \\
\hline Panama Canal & 294.1 & 32.3 & 12 \\
\hline Panama Canal expansion & 366 & 49 & 15 \\
\hline Suez Canal & No-limitation & 77 & 20 \\
\hline
\end{tabular}

Source: Based on Canal Web Data

The increased capacity of ULCV has reduced freight costs. Orders for container ships have doubled in recent years (González, 2008).

In the race to form part of the maritime "hub club", seaports such as Shanghai (ranking first worldwide) and Rotterdam (Europe's largest port) wield a considerable advantage, due to the ease with which they can adapt their infrastructures to the arrival of ULCV. In comparison, inside seaports that face numerous disadvantages: tides or the need to carry out dredging in order to deepen their approach channels. The European inside seaports of Hamburg and Antwerp are two examples of this struggle to retain competitiveness in the world ranking of ports. We have used the term "inside seaport" to refer to that seaports located far away from the estuary, with a narrow channel and it's necessary to ride the tide. 
Our paper essentially focuses on a study of the theoretical framework of the subject, and on an analysis of two representative cases, the inland waterway ports of Hamburg and Antwerp. To this end, we will examine three aspects that we consider crucial: ULCV navigation in these two ports; the challenge that ULCV transit through inland waterways poses for aids to navigation systems, analysing the case of the Elbe and Scheldt rivers; and the efforts of the Hamburg and Antwerp port authorities to maintain competitiveness. The basic question to determine in these cases is whether the intervention of the German and Belgian governments and the European Union will suffice to ensure that these ports remain in the select club of maritime hubs, or

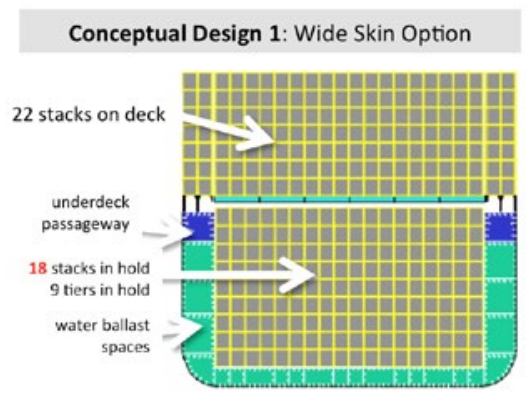

Fig. 1.

Conceptual Design - ULCV

Source: Based on (Tozer \& Penfold, 2001)

ULCV have been designed to increase cargo capacity, achieved by changing the position of the bridge from its traditional location above the engine room to the centre of the hull, while still respecting the visibility criteria stipulated by the International Maritime Organisation (IMO) (Tozer and if the continued trend towards mega-ULCV will eventually mean that only seaports will be able to cope with this kind of maritime traffic.

\section{Theoretical Framework}

\subsection{The Concept of ULCV}

They can be divided into two types: one characterised by having 7 levels and 22 rows of containers on deck, with another 9 levels and 18 rows of containers in the hold, which can transport 12,100 TEU; and the other characterised by having a greater cargo capacity in the hold, with one extra row on each side, which can transport between 12,500 TEU and 13,000 TEU (Figure 1).

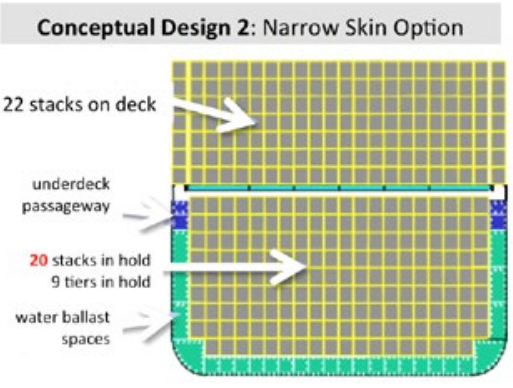

Penfold, 2001), and these days they can carry over 18,000 TEU.

In order for this type of ship to be able to dock, ports require sufficient depth of the approach channel and docks, large areas for manoeuvres, adapted cranes and a larger yard. 


\subsection{Navigable Inland Waterways}

In the past decades considerable changes has undergone in the maritime transport safety control. Almost fifty years ago, some papers in this journal alerted about the problems of safety of Navigation on Inland Waterways in Europe or Japan (Beattie, 1962; NPA, 1968; Onishi, 1968).

A navigable inland waterway is defined as any stretch of water, canal or lake, which due to natural or artificial features, is suitable for navigation, especially for inland boats (Directive 80/1119/EEC).

The Permanent International Association of Navigation Congresses (PIANC) defines several concepts related to the configuration of maritime ports in its report N.121-2014.
First, the approach channel is defined as a stretch of waterway connecting the port docks with the open sea, and can be of two types: an outer channel in open sea, exposed to the waves and therefore capable of producing rolling and pitching motions on vessels; and an inner channel which is protected from the action of the waves.

A distinction is made between channel and waterway. The channel is the deepest area, whether natural or dredged, with sufficient width and depth to allow the safe passage of deeper draught vessels. Some countries, however, define the waterway as suitable for all types of ship, across its entire width, including the channel and shallower areas for the transit of smaller ships. In both cases, the boundaries are marked with buoys, as shown in Figure 2.

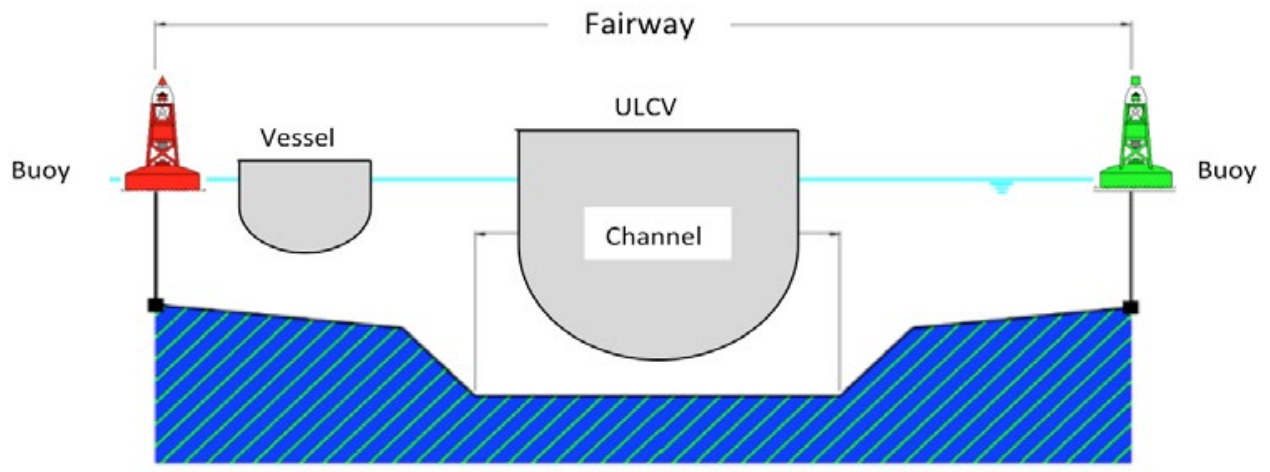

Fig. 2.

Channel and Waterway

Source: Based on PIANC. Report no 121-2014

The main aspects of the physical environment to consider are: tides, which affect the depth of the channel and may oblige larger vessels to navigate at high tide; visibility, which tends to be reduced by fog; currents; wind; and even ice formation.
Ships initiate transit during the "tidal window", which is the period of time between high tide in the landfall area at open sea and high tide in the inner harbour docks. This is when the channel offers maximum depth and thus ensures under keel clearance. They 
generally set sail an hour before high tide in order to leverage the tidal wave (IALAAISM, 2014).

\subsection{Aids to Navigation (AtoN)}

In SOLAS-V/13 ("Safety of navigation" IMO, 1974), IMO established that each State shall provide the aids to navigation appropriate to the level of traffic and the degree of risk. This requires that contracting States apply uniformly standardised aids to navigation. To achieve this, the International Association of Lighthouse Authorities (IALA) was created in 1957. IALA defines aids to navigation as systems external to the ship capable of helping determine its position and course, warning about dangers and obstacles and indicating the best route to follow.
In appendices 2 and 3 of Resolution A.915 (22), the IMO indicates that the absolute horizontal accuracy of aids to navigation regarding vessel position on inland waterways should be 10 metres, with a probability of $95 \%$. The accuracy of nautical charts is also very important. The national authority responsible for their publication must work in coordination with the body responsible for aids to navigation. In the particular case of restricted waters, the nautical chart scale is $1: 10000$, requiring an accuracy of $10 \mathrm{~m}$ (IALA-AISM, 2014).

Aids to navigation include visual aids (lighthouses, beacons, buoys and leading lines), electronic navigation, which we will discuss later, a pilotage service and traffic organisation boats (Figures 3 and 4).

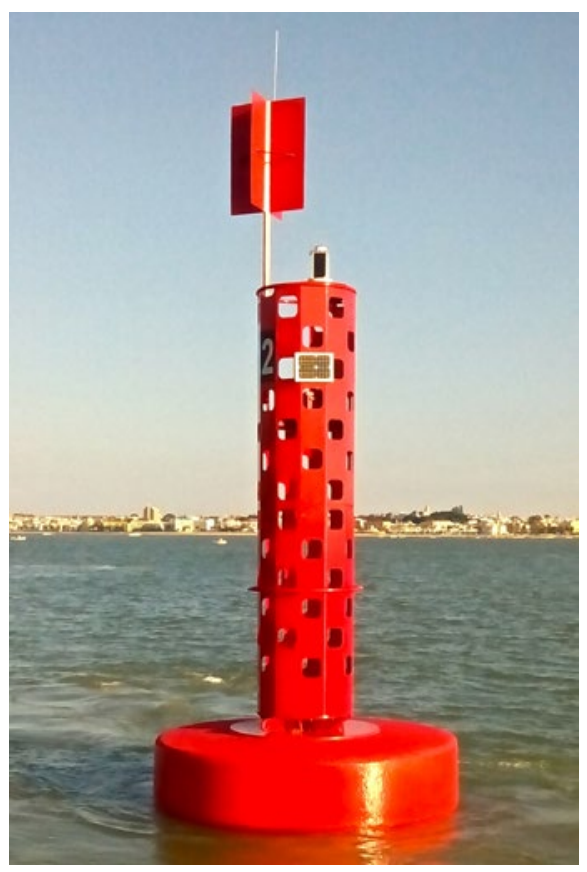

Fig. 3.

Example of River Buoy at the Estuary, Marking the Limits of a Dredged Channel 


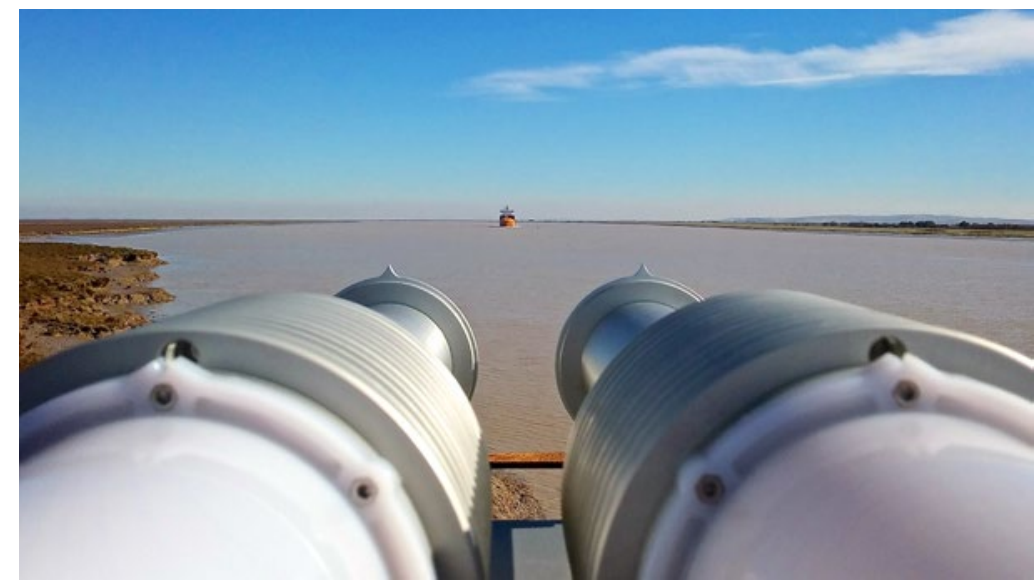

Fig. 4.

LED Sector Lights Marking the Centre Line of the Channel of River (Extremely Precision)

It is important to measure the Risk Assessment for AtoN, not only using the IALA method, even the Fuzzy-FSA on Three-Dimensional Simulation System used in the deep-water channel of the Yangtze River estuary (Chen, 2014). It takes into account traffic volume, ship traffic conditions, navigational conditions, waterway configuration and accident conditions. It obtains a score as a result.

\subsection{Under Keel Clearance (UKC)}

The PIANC defines UKC, as the distance between the ship's keel and the bottom of the channel. The factors used to calculate this distance are the reference level of the water, which depends on the height of the tide at the time, and the nominal level of the bottom of the channel, which is the level above which no obstacles to navigation should be found (PIANC, 1985). There are two concepts of UKC:

- Gross UKC: this is the theoretical value of the margin between the ship's keel and the nominal level of the channel bottom, measured in calm waters. It allows for an increase in draught due to uneven loading, changes in salinity along the estuary, squat (the effect of speed on draught: the higher the speed, the lower a ship sits in the water), response to the wind and waves, and a safety margin.

- Net UKC: this can be calculated using a deterministic approach, which is the minimum margin between the nominal level of the bottom and the ship's keel in the most unfavourable position. If all the elements included in the gross $\mathrm{UKC}$ are assigned maximum values, then the net UKC can be considered an additional safety measure. The UKC can also be calculated using a probabilistic approach, taking into account errors, uncertainties and variations in values.

It is also important to highlight the effect of the current: this is significantly greater when the UKC is small, and affects ship manoeuvrability, which is considerably better when sailing into the current (Figure 5). 


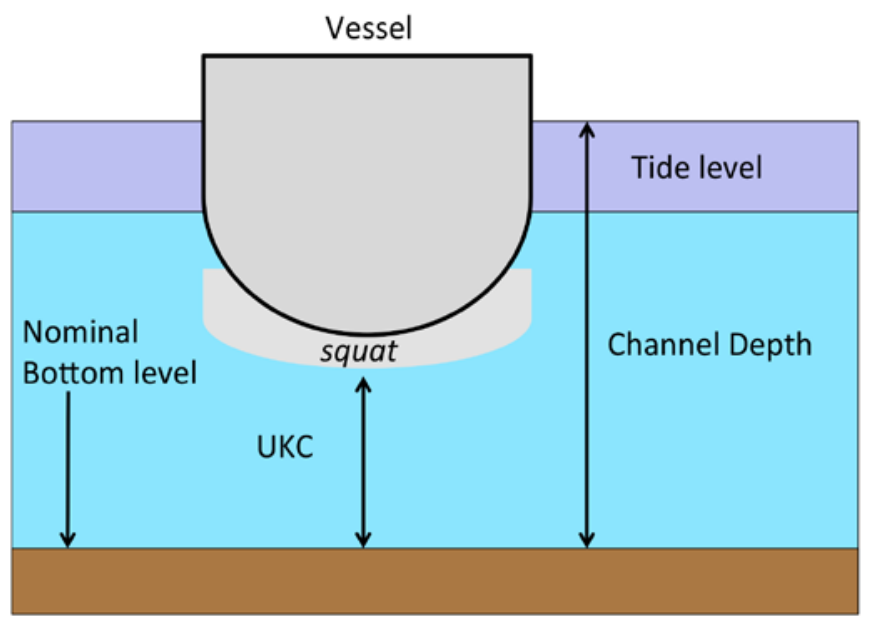

Fig. 5.

Under Keel Clearance (UKC)

The minimum safe UKC value that also guarantees ship manoeuvrability is $1 \mathrm{~m}$ (PIANC, 1985). With a deterministic approach, the safety criterion established for the minimum net UKC is that applied in the ICORELS report (PIANC, 1985), which recommends a minimum value of $0.5 \mathrm{~m}$, allowing a value of $1 \mathrm{~m}$ when the chances of touching the bottom are high (PIANC 1985). Alternatively, the IMO Helsinki Committee has indicated that the UKC should be $10 \%-$ $20 \%$ of the ship's draught. This Committee, also known as HELCOM, works to protect the Baltic Sea environment. It is based on regional agreements involving the EU and Denmark, Estonia, Finland, Germany, Latvia, Lithuania, Poland, Russia and Sweden (Swedish Transport Agency, 2015).

Currently, inland ports employ UKC management systems based on software applications that calculate probabilistic tidal windows and incorporate real-time monitoring systems during transit (IALAAISM, 2014).
These systems employ dynamic data, including water level and density, the current, the wind and wave height and direction, which are measured by devices installed along the waterway, such as tide gauges, current meters or wave-measuring buoys. Static data are also used, such as the ship's characteristics (wave response, draught at bow, mid-length and stern), squat and actual depth (IALA-AISM, 2014).

When the authorities responsible decide to implement UKC management systems, the maximum draught of vessels admitted in the channel is increased, although the use of a probabilistic tidal window implies that the greater the ship's draught, the greater the likelihood that it will have to wait one or more tides (IALA-AISM, 2014).

\subsection{E-navigation}

The first decade of the 21 st century has witnessed the development of e-navigation for traffic and transport management support 
services. The river information services (RIS) system is of particular importance for inland waterways, and will be discussed later in the state-of-the-art section. However, other systems are also increasingly being used to improve safety, surveillance, reliability and efficiency of maritime and river transport, although this requires a more integrated and coordinated approach to ensure that these technologies represent added value rather than posing an obstacle.

Thus, as new systems are developed, there is a growing need for standardisation and efficient, simplified, interoperable solutions that reduce the burden for users and are integrated with systems throughout the transport chain (IALA-AISM, 2014), highlighting the $S$-Mode who arranges all the on-board electronic systems by pressing one single button (Patraiko, 2007).

In 2008, the IMO Maritime Safety Committee defined e-navigation as the harmonised collection, integration, exchange, presentation and analysis of marine information on board and ashore by electronic means to enhance berth to berth navigation and related services for safety and security at sea and protection of the marine environment (IMO. E-navigation).

The objectives of e-navigation are: to facilitate the safe navigation of vessels with regard to hydrographical, meteorological and navigation information, facilitate maritime traffic management, facilitate communication and provide opportunities to improve the efficiency of transport and logistics. E-navigation is a concept that incorporates systems and services (Patraiko, 2007). Some of the most important e-navigation systems are:
- The Automatic Identification System (AIS): It is used in traffic coordination centres, tracking vessels in real-time on digital maps. In 2000, the IMO adopted the AIS as part of Regulation 19 of Chapter V of the SOLAS Convention (IMO. AIS Transponders). Furthermore, virtual Aids to Navigation don't physically exist and they are provided by AIS stations and they are showed on ENC. There are a lot of applications, for example, they can mark new risks at the time they are known or they can mark the deepest areas in a fairway (IALA-AISM, 2010).

- The Differential Global Positioning System (DGPS): an enhancement to GPS that improves accuracy to under 3 metres, by means of a ground-based network of reference stations.

- Radar, racons and radar reflectors: radar allows a ship to identify targets such as racons and reflectors installed on buoys and beacons. It also allows traffic coordination centres to identify ships. Vessel Traffic Services (VTS) systems: they are usually equipped with radar sensors, closed circuit television (CCTV), AIS, VHF and meteorological and hydrological stations.

- Vessel Traffic Management (VTM) system: a new, more comprehensive concept of VTS composed of harmonised media and services to improve safety, surveillance, navigation efficiency and protection of the marine environment in all navigable waters (IALA-AISM 2014).

- Electronic Chart Display and Information System (ECDIS): the new generation of electronic nautical charts (ENC) on electronic media, which also provides additional information such as bathymetry or hydrological data. 
- Among the services, e-navigation provides comprehensive data in standard format, and infrastructure to transfer the data (Patraiko, 2007).

Another recent concept is that of e-Maritime, through which the European Commission, in its communication COM92009 8, "Strategic goals and recommendations for the EU's maritime transport policy until 2018", aims to improve the efficiency of maritime transport in Europe and to ensure its longterm competitiveness. This consists of a series of policies, strategies and capabilities to facilitate online or electronic interaction between the different agents involved in the development of a sustainable and efficient maritime transport system throughout Europe that is fully integrated with logistic transport chains.

\section{The Role of the European Union in Inland Navigation}

The European Union recognises the great potential of inland waterway navigation and promotes increased efficiency and safety through the use of information and communication technologies.

Directive 2005/44/EC of the European Parliament and of the Council of 7 September 2005 , on harmonised river information services (RIS) on inland waterways in the Community, is aimed at coordinating efforts and standardising a model of aids to navigation systems in order to facilitate the navigation of vessels on inland waterways.

This directive establishes the requirements and technical specifications for implementing RIS systems, based on the work of the International Association of Navigation, the Central Commission for Navigation on the Rhine and the Economic Commission for Europe of the United Nations (UNECE).

It is applicable to all inland waterways of the Member States of class IV and above (according to the classification of European inland waterways in Resolution 92/2 of the European Conference of Ministers of Transport and in Resolution 30 of the UNECE, of 12 November 1992) which are linked by a waterway, even between Member States, including the ports on such waterways. Member States, which have inland waterways falling within this scope, must transpose this directive into national law.

The goal of RIS is to enhance safety, efficiency and respect for the environment through traffic and transport management and protection of the environment and infrastructures. It includes various previously mentioned technologies, primarily AIS, DGPS, ECDIS, VTS, radar, warnings to navigators and hydrological information. It also includes accident prevention services, information on transport management, statistics and customs services and calculation of levies and fees for the use of waterways and their ports. All these technologies are interoperable and integrated.

The associated ECDIS is now called Inland ECDIS to distinguish it from Maritime ECDIS, although the two are mutually compatible. In reality it is similar, but contains more complete information since it includes all the necessary information about the navigation channel (waterway boundaries, fairway, buoyage, channel depth, water level, etc.), and the chart can be superimposed on the radar image. It also gives information on restrictions for vessels 
or convoys in terms of length, beam, draught and air draught, operation times of locks and bridges, and the location of ports and transhipment points.

Information on the main EU projects and European legislation on AIS technology is available at River Information Services portal (RIS). RIS technology for the Danube River is particularly comprehensive (Danubian Region Strategy website), and the Observatory of European Inland navigation has also publicised RIS technology.

European Union legislation concerning Directive 2005/44/EC has been established by the European Commission through various regulations drawn up by technical committees.

In addition, the UNECE has also made its own recommendations on the AIS standard (UNECE).

\section{Methodology}

The first step in the present research was to select the inside seaports to study. The top European ports in the world ranking of container ports are Rotterdam, Hamburg and Antwerp. Since these latter two are inside seaports, they were selected for this case study. Their variables are summarised in Table 2 .

\section{Table 2}

Characteristics of Antwerp and Hamburg Inland Waterways

\begin{tabular}{|l|l|l|l|l|l|}
\hline Port / River & $\begin{array}{l}\text { Canal } \\
\text { length }\end{array}$ & $\begin{array}{l}\text { Canal draft } \\
\text { at Low tide }\end{array}$ & $\begin{array}{l}\text { Height } \\
\text { of tide }\end{array}$ & $\begin{array}{l}\text { Allowed } \\
\text { vessels }\end{array}$ & $\begin{array}{l}\text { Idem. Maximum draft } \\
\text { entry/departure }\end{array}$ \\
\hline Hamburg/Elbe & $115 \mathrm{Km}$ & $12.8 \mathrm{~m}$ & $3.66 \mathrm{~m}$ & $12.8 \mathrm{~m}$ & $15.8 \mathrm{~m} / 13.8 \mathrm{~m}$ \\
\hline Antwerp/Scheldt & $80 \mathrm{Km}$ & $13.1 \mathrm{~m}-14.5 \mathrm{~m}$ & $5.3 \mathrm{~m}$ & $13.1 \mathrm{~m}$ & $16 \mathrm{~m} / 15.2 \mathrm{~m}$ \\
\hline
\end{tabular}

Source: Based on Canal Web Data

The port of Hamburg is located $115 \mathrm{~km}$ from the North Sea and is accessed via the River Elbe and in 2013 it received 9,302 million TEU, representing a 5\% increase on 2006. It has not proved possible to increase channel depth due to policies that restrict dredging. Without tidal assistance, ships with a maximum draught of $12.8 \mathrm{~m}$ can enter the port, while high tide permits the entry of vessels with a maximum draught of $15.8 \mathrm{~m}$ and the departure of ships with a maximum draught of $13.8 \mathrm{~m}$. The depth of the channel at low tide is $12.8 \mathrm{~m}$, and the river has a tidal range of $3.66 \mathrm{~m}$ (TIDE, 2012; Port of Hamburg, 2015).

The port of Antwerp is located $80 \mathrm{~km}$ from the North Sea and is accessed via the
River Scheldt. In 2013, it received 8,578 million TEU, representing a $22 \%$ increase on 2006. Dredging to increase channel depth concluded in 2011, creating a draught at low tide that ranges between $13.1 \mathrm{~m}$ and $14.5 \mathrm{~m}$, with a tidal range of $5.3 \mathrm{~m}$. Without tidal assistance, ships with a maximum draught of $13.1 \mathrm{~m}$ can enter the port, while high tide permits the entry of vessels with a maximum draught of $16 \mathrm{~m}$ and the departure of ships with a maximum draught of $15.2 \mathrm{~m}$ (TIDE, 2013; Port of Antwerp, 2015).

Thus, we analysed the entry of ULCV in the ports of Hamburg and Antwerp. First, we selected various ULCV belonging to different shipping lines, and then tracked their trajectories using AIS data obtained 
online for the period January to July 2015. We also monitored the tidal coefficient when one of these ships called at Hamburg or Antwerp.

Subsequently, we sought information about modifications to aids to navigation or the implementation of new technologies that would have facilitated the entry of these vessels.

In a final step, we compared the results obtained for the ports of Hamburg and
Antwerp, measured as TEU, with those for the seaport that we considered representative in the area, the port of Rotterdam.

\section{Case Study: Ports of Hamburg and Antwerp}

ULCV tracking revealed that $78 \%$ of these vessels called at the port of Hamburg, and a considerably lower number, $29 \%$, at Antwerp. Table 3 gives a list of the selected ships with their dimensions and calls at the ports analysed.

Table 3

Dimensions of Selected Ships with their and Calls at the Ports

\begin{tabular}{|l|l|l|l|l|l|}
\hline Name of the vessel & Length $(\mathbf{m})$ & Beam $(\mathbf{m})$ & Draught $(\mathbf{m})$ & TEUs & $\begin{array}{l}\text { Calls at the ports } \\
\text { analysed }\end{array}$ \\
\hline Maersk Mc-Kinney Moller & 399 & 59 & 16 & 18.340 & -- \\
\hline Edith Maersk & 397 & 56 & 16 & 15.500 & Antw./Hamb. \\
\hline Mary Maersk & 399 & 59 & 16 & 18.340 & Antw. \\
\hline Emma Maersk & 397 & 56 & 16 & 15.500 & Antw./Hamb. \\
\hline CMA CGM Marco Polo & 396 & 53,6 & 16 & 16.020 & Hamb. \\
\hline $\begin{array}{l}\text { CMA CGM Alexander Von } \\
\text { Humboldt }\end{array}$ & 396 & 53,6 & 16 & 16.020 & Hamb. \\
\hline CMA CGM Kerguelen & 398 & 54 & 16 & 17.722 & Hamb. \\
\hline CMA CGM Jules Verne & 396 & 53,6 & 16 & 16.020 & Hamb. \\
\hline CSCL Globe & 400 & 59 & 16 & 19.100 & Hamb. \\
\hline CSCL Pacific Ocean & 400 & 59 & 16 & 19.100 & Hamb. \\
\hline CSCL Indian Ocean & 400 & 59 & 15,6 & 18.980 & Hamb. \\
\hline Hanjin Sooho & 366 & 59 & 16 & 13.102 & Hamb. \\
\hline MSC Oscar & 395 & 399 & 54 & 19.224 & -- \\
\hline MSC New York & & 18.270 & Antw./Hamb. \\
\hline SOurce: Based on AIS data & & & & \\
\hline
\end{tabular}

Source: Based on AIS data

In the case of the Elbe River, the water level at St. Pauli (the heart of the port of Hamburg) is not higher when the tidal coefficient is higher (see Table 4). This may be due to the existence of resonance phenomena in the tidal wave, indicating the need for a detailed study of the behaviour of the tidal wave along the waterway (TIDE, 2011). 


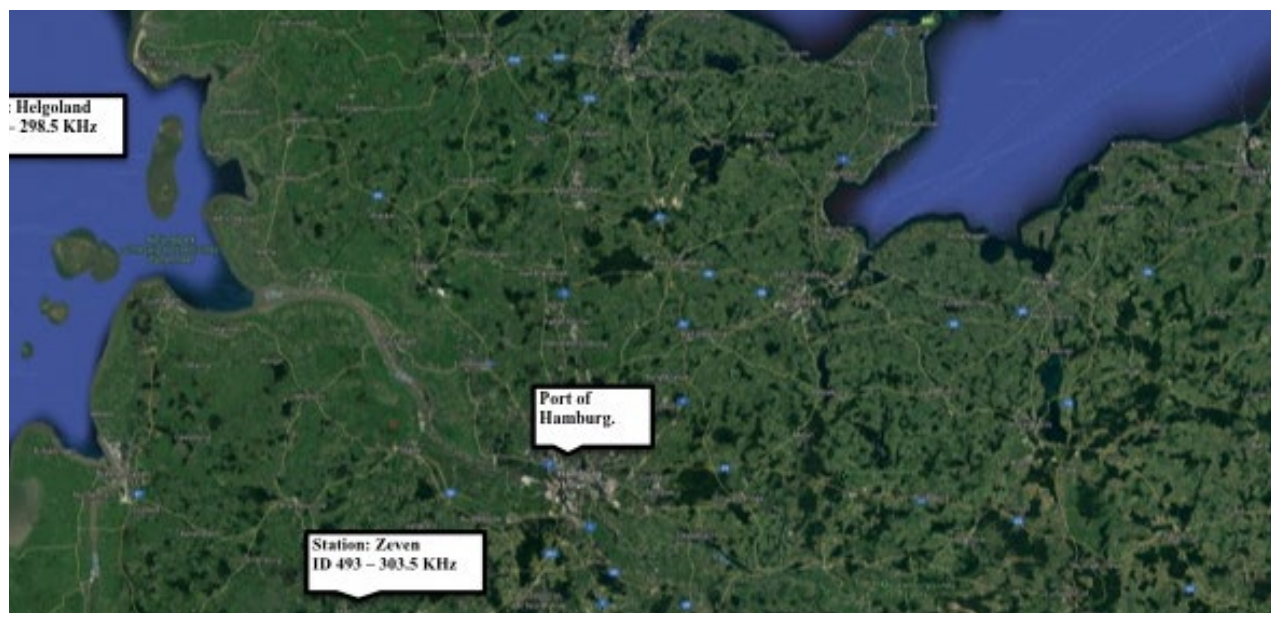

Fig. 6.

IALA DGPS Reference Stations: Port of Hamburg

Source: Based on Google Earth@ and Data from http://www.gnsspro.com

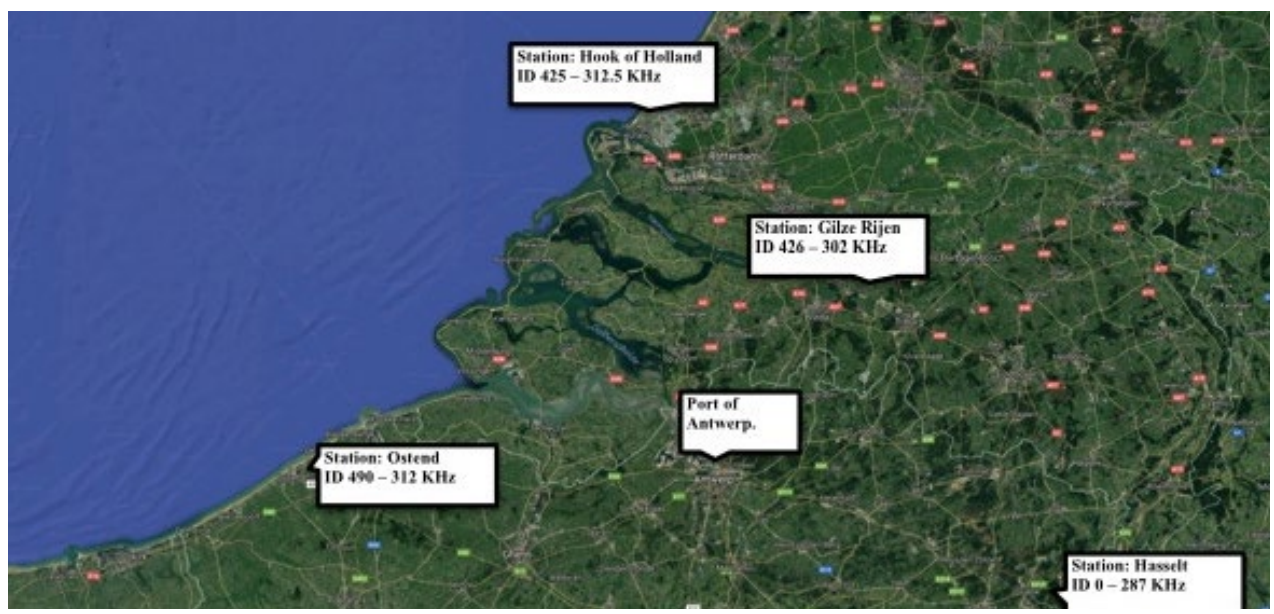

Fig. 7.

IALA DGPS Reference Stations: Port of Antwerp

Source: Based on Google Earth $@$ and Data from http://www.gnsspro.com

jitte 12 
Table 4

Tidal Coefficient Hamburg Port, St. Pauli (Maximum Recorded High Tide 4.3m)

\begin{tabular}{|l|l|}
\hline Tidal coefficient. & Height of High Tide $(\mathbf{m})$ \\
\hline 42 & 3.9 \\
\hline 44 & 3.9 \\
\hline 47 & 4.0 \\
\hline 54 & 4.0 \\
\hline 55 & 3.7 \\
\hline 58 & 3.7 \\
\hline 60 & 3.5 \\
\hline 63 & 4.0 \\
\hline 66 & 3.6 \\
\hline 77 & 3.9 \\
\hline 80 & 3.8 \\
\hline 81 & 3.8 \\
\hline 87 & 4.0 \\
\hline 99 & 4.1 \\
\hline 105 & 4.1 \\
\hline 106 & 4.2 \\
\hline 114 & 4.0 \\
\hline
\end{tabular}

Source: Based on Hamburg Port Data

http://www.tablademareas.com/de/hamburg/hamburg-st-pauli

The same results were not found for the River Scheldt. As a result of tidal resonance in estuaries and inland waterways, the tidal range in estuaries is greater than that in the open sea. In addition, the flood tide coincides with the ebb tide, especially in very long waterways. This phenomenon causes irregular behaviour in the tidal wave along the length of the estuary, as shown in any manual (The World Energy Conference, 1986).

The ULCV studied here entered during the tidal window, since entry without tidal assistance is limited to vessels with a maximum draught of 13 metres. This restricts the entrance of ULCV to two tidal windows a day. ULCV can also enter with the tidal window almost at their nominal draught, but must leave the ports with less cargo; in this respect, Antwerp offers better possibilities $(15.2 \mathrm{~m})$ than Hamburg $(13.8 \mathrm{~m})$.

At both ports, exported goods differed from imported ones. At Hamburg for instance, Germany exports machinery, a very heavy commodity, but imports much lighter goods such as textiles and electronic goods. Consequently, ships can carry their maximum capacity when entering the port, but must carry a reduced load on departure due to the limitations on draught when leaving Hamburg (Port of Hamburg, 2013).

We found no information regarding the installation of new visual aids to navigation for ULCV on the Scheldt and Elbe rivers, probably indicating that they were not necessary; this is not surprising since the fairway should already be marked by existing maritime signals. Furthermore, a review of the digital cartography revealed that both fairways are mainly marked by buoys, which are easily adapted to changes in the sandbars that are periodically verified through bathymetry. Both channels, have all kind of AtoNs, mixing them and providing the highest accuracy by DGPS, vessels know where other vessels are by AIS, limits of 
the channel are marking for example by PEL (Port Entry Light), and buoys that are marking grounds in the channel.

An analysis of e-navigation use in the two waterways showed that the port of Hamburg uses information technology (IT) aids, which are shared with terminal operators and pilots to ensure that these are making the most effective use possible of the tidal window. These include ECDIS, the Port River Information System Elbe (PRISE, the RIS of the Elbe River) and the Marine Training Centre (MTC) simulator at Hamburg-Stellingen, where pilots are trained to manoeuvre new types of ship on the Elbe. The simulator enables pilots to make accurate calculations for the vessel concerned, and visualise the impact of currents, strong winds, ice formation, fog and complicated encounters with other vessels on the Elbe or in the port. Together with the port authority, pilots process simulation variables to develop a personalised plan (Port of Hamburg, 2014).

Other measures being taken on the Elbe are related to infrastructures that optimise tidal windows. These include the creation of a "passing box", which makes it possible for ULCV to pass each other without needing to wait, and widening of the turning circle at the container terminals. For pilots and tugboat pilots, turning a ULCV within a minimum time is a great challenge (Port of Hamburg, 2014). On the other hand, Port of Hamburg has created a new type of barge vessel called
Port Feeder Barge that includes an innovative type of efficient barge vessel with a capacity of $168 \mathrm{TEU}$, equipped with a crane with an automatic spreader (Malchow, 2014). This barge achieves transport the containers far away where before was no possible because of shallow water restrictions for ULCV.

A previous study at the port of Antwerp, conducted by Flanders Hydraulics Research and the port authority (2003) with the collaboration of pilots, tugboat pilots and shipping companies, investigated the feasibility of navigating Maersk S class ships on the Scheldt. Regulations at the time did not allow vessels over $340 \mathrm{~m}$ long to navigate the Scheldt. The study examined two aspects related to the manoeuvrability of these vessels on inland waterways: navigation along the Scheldt of ULCV with a maximum capacity of 14,000 TEU, and access to the terminals. It also evaluated the need for dredging, concluding that this was necessary to deepen the channel. In 2011, the Scheldt was dredged until obtaining a depth of $14.5 \mathrm{~m}$, allowing the unrestricted entrance of ULCV within the tidal window (Eloot, Verwilligen and Vantorre, 2010).

By way of comparison, the "open" port of Rotterdam is the main North Sea competitor of Hamburg and Antwerp and Europe's largest port. Although the data for this port indicate that it has witnessed exponential growth (20\%), it nevertheless ranks eleventh in the world rankings (Table 5).

\section{Table 5}

Containerization Main European Ports - Millions TEUs

\begin{tabular}{|l|l|l|l|l|l|l|l|l|l|}
\hline Port / year & 2006 & 2007 & 2008 & 2009 & 2010 & 2011 & 2012 & 2013 & Variation \\
\hline Rotterdam & 9655 & 9900 & 10800 & 9743 & 11145 & 11876 & 11865 & 11621 & $+20.36 \%$ \\
\hline Hamburg & 8862 & 9360 & 9737 & 7007 & 7900 & 9014 & 8863 & 9302 & $+4.96 \%$ \\
\hline Antwerp & 7019 & 8355 & 8664 & 7309 & 8468 & 8664 & 8633 & 8578 & $+22.21 \%$ \\
\hline
\end{tabular}

Source: Based on IAPH Web Data (International Association of Ports and Harbours)

\section{jitte 14}


Of the ships analysed, 24 called at the port of Rotterdam, compared with 17 at the port of Hamburg (29\% fewer) and 9 at the port of Antwerp (62\% fewer), indicating that the trend towards increasingly larger container ships has accentuated still further the ascendancy of this seaport over the inland ports.

\section{Discussion and Conclusions}

The increasing size of ULCV has prompted some ports to specialise in these ships; however, due to their sheer scale, such specialisation is much easier for seaports and has proved a challenge for inside seaports.

ULVC can only enter inside seaports during the tidal window, i.e. twice a day. Undoubtedly, the most effective measure to ensure access for larger ships would be to increase approach channel depth, but environmental organisations often take legal action to prevent this.

The data presented here suggest that under the current situation, while dredging project is under study, Aids to Navigation systems are important to achieve ULCV can arrived to inside seaports where before was impossible, so to improve competitiveness. We therefore draw eight basic advices to study whether they were possible to apply in order to study how to increase competitiveness in inside seaports:

1. Visual aids to navigation cannot yield further improvements to navigation efficiency, but it is necessary to ensure that all kind of visual AtoN mark the deepest areas of the channel.
2. There is a need to develop existing software applications for ship configuration and real-time analyses of their UKC in relation to the tidal window.

3. Inside seaports require new infrastructures, such as passing boxes, and larger turning circles. Also, if it were possible, create new Port Feeder Barge.

4. Navigable rivers should be monitored by installing sensor networks along waterways. These would make it possible to obtain real-time data on tides, currents, salinity, wind, etc., and to study the behaviour of these variables.

5. Bathymetric studies should be conducted at regular intervals.

6. Close collaboration with pilots is important, and these should receive updated training that includes the use of simulators to analyse the behaviour of these new ships.

7. The use of the e-navigation is vital to reduce navigational accidents. Vessels must include harmonized systems such as S-Mode.

8. Information technology systems that exploit and share data are also crucial.

Using a combination of these eight proposals, and taking full advantage of tidal windows and passing boxes, ULCV can enter the Scheldt and Elbe rivers without compromising security, although great care must be exercised. We recommend using them in the channels of the inside seaports if possible, taking into account these successes. As a result, it is possible the research might figure out that largest vessels could entry to the channel taking advantage of the deepest areas and the most safety and more accurate systems. 


\section{References}

Beattie, J.H. 1962. Safety of Navigation on Inland Waterways in Europe, The Journal of Navigation 15(1): $49-52$.

Chen, J.; Chen, T.; Shi, C.J.; Jia, D. 2014. Real-time Risk Assessment for Aids to Navigation Using Fuzzy-FSA on Three-Dimensional Simulation System, TransNav the International Journal on Marine Navigation and Safety of Sea Transportation, 8(2): 197-203.

Danubian Region Strategy website available at http:// www.danube-navigation.eu/pages/projects/ris Accessed: 10/11/2016.

Economic Commission for Europe (ECE). 2005. Guidelines and Criteria for Vessel Traffic Services on Inland Waterways. Resolution N.58. Inland Transport Committee (ITC). Working Party on Inland Water Transport.

ECE. 2012. Guidelines and Recommendations for River Information Services. Revision 1. ITC Working Party on Inland Water Transport.

ECE. 2013. Recommendation on Electronic Chart Display and Information System for Inland Navigation. Resolution N.48. Revision 2. ITC Working Party on Inland Water Transport.

ECE. 2015a. International Standard for Electronic Ship Reporting in Inland Navigation. Resolution N.79. ITC Working Party on Inland Water Transport.

ECE. 2015b. International Standard for Notices to Skippers in Inland Navigation. Resolution N.80. ITC Working Party on Inland Water Transport.

ECE. 2015c. International Standard for Tracking and Tracing on Inland Waterways (VTT). Resolution N.63. Rev. 1. ITC Working Party on Inland Water Transport.
Eloot, K.; Verwilligen, J.; Vantorre, M. 2010. Synergy between theory and practice for Ultra Large Container Ships. PIANC MMX Congress Liverpool. 13 p. Available from internet: www.vliz.be/imisdocs/ publications/211488.pdf accessed 10/02/2017.

Economic Commission for Europe of the United Nations (UNECE) http://www.unece.org/trans/main/sc3/ sc3res.html Accessed: 02/11/2016.

European Union (EU). 2005. Directive 2005/44/EC of the European Parliament and of the Council of 7 September 2005 on Harmonised River Information Services (RIS) on Inland Waterways in the Community.

European Union (EU). 2007a. Commission Regulation (EC) N.414/2007 of 13 March 2007 concerning the Technical Guidelines for the Planning, Implementation and Operational use of River Information Services (RIS).

European Union (EU). 2007b. Commission Regulation (EC) N.415/2007 of 13 March 2007 concerning the Technical Specifications for Vessel Tracking and Tracing Systems referred to in Article 5 of Directive 2005/44/ EC of the European Parliament and of the Council on Harmonised River Information Services (RIS).

European Union (EU). 2007b. Commission Regulation (EC) N.416/2007 of 22 March 2007 concerning the Technical Specifications for Notices to Skippers as referred to in Article 5 of Directive 2005/44/EC of the European Parliament and of the Council on Harmonised RIS on Inland Waterways in the Community.

European Union (EU). 2010. Commission Regulation (EU) N.164/2010 of 25 January 2010 on the Technical Specifications for Electronic Ship Reporting in Inland Navigation referred to in Article 5 of Directive 2005/44/ EC of the European Parliament and of the Council on Harmonised RIS on Inland Waterways in the Community. 
European Union (EU). 2012. Commission Implementing Regulation (EU) N.689/2012 of 27 July 2012 amending Regulation (EC) N.415/2007 concerning the Technical Specifications for Vessel Tracking and Tracing Systems referred to in Article 5 of Directive 2005/44/EC of the European Parliament and of the Council on Harmonised RIS on Inland Waterways in the Community.

González Laxe, F. 2007. El Contenedor: La Caja que cambió el Mundo Económico. repercusiones sobre la Galicia Marítima. /The Container: The box that changed the Economic World. Impacts on Maritime Galicia/ Instituto Universitario de Estudios Marítimos. Edit. Universidade da Coruña. Doc. 2/2007: 1-10.

González Laxe, F. 2008. Nuevas tendencias en el transporte marítimo, Revista Galega de Economía 17(1): 5-28. Available from internet: http://www.usc.es/econo/ RGE/Vol17_1/castelan/art1c.pdf accessed 10/02/2017

International Association of Marine Aids to Navigation and Lighthouse Authorities (IALA-AISM). 2014. Navguide 2014. Aids to Navigation Manual. Seventh edition.

International Association of Lighthouse Authorities (IALA). 2010. Recommendation O-143 on virtual Aids to Navigation.

International Association of Ports and Harbours (IAPH). 2014. Statistics: World Container Traffic Data 2014. Available from internet: http://www. iaphworldports.org/LinkClick.aspx?fileticket $=\mathrm{A} 7 \mathrm{o}$ Mk7mR0a4\%3d\&tabid $=4879$

International Maritime Organization (IMO). 1974. Safety of Life at Sea Convention SOLAS - Chapter V, Safety of Navigation. Regulation 13: Establishment and operation of Aids to Navigation.

IMO. 2015a. AIS Transponders. Available from internet: http://www.imo.org/en/OurWork/Safety/Navigation/ Pages/AIS.aspx Accessed: 14/08/2015.
IMO. 2015b. E-navigation. Available from internet: http://www.imo.org/en/OurWork/Safety/Navigation/ Pages/eNavigation.aspx Accessed: 15/08/2015.

Maersk. 2015. The World's Largest Ship. Maersk. Available from internet: http://www.maersk.com/ en/hardware/triple-e.pdf Accessed: 19/07/2015.

Malchow, U. 2014. Port Feeder Barge: Advanced Waterborne Container Logistics for Ports, TransNav the International Journal on Marine Navigation and Safety of Sea Transportation 8(3): 411-416.

Muñoz, A. 2014. EEUU aprueba la nueva alianza de navieras 2M, con Maersk y MSC /US approves new shipping alliance with 2M, Maersk and MSC/. Europa Sur. 15/10/2014. Available from internet: http:// www.europasur.es/article/maritimas/1877692/eeuu/ aprueba/la/nueva/alianza/navieras/m/con/maersk/y/ msc.html Accessed: 16/07/2015.

Netherlands Pilots' Association (NPA). 1968. Collisions in the River Scheldt, The Journal of Navigation 21(4): $448-464$.

Observatory of European Inland navigation website. Available from internet: http://www.inland-navigation. org/observatory/innovation-technologies/informationservice/ Accessed: 13/11/2016

Onishi, T. 1968. Handling Large Vessels in the Port of Hirohata, The Journal of Navigation 21(2): 155 - 162.

Panama Canal Authority. 2015. ¿Qué es el programa de Ampliación del Canal de Panamá? /What is the Panama Canal Expansion Program?/ Available from internet: https://micanaldepanama.com/ampliacion/preguntasfrecuentes/ Accessed 14/07/2015.

Patraiko, D. 2007. The Development of e-Navigation, TransNav the International Journal on Marine Navigation and Safety of Sea Transportation 1(3): 257-260. 
Permanent International Association of Navigation (PIANC). 1985. Underkeel clearance for large ships in maritime fairways with hard bottom. Report of a working group of the Permanent Technical Committee II. Supplement to Bulletin no 51 .

Permanent International Association of Navigation (PIANC). 2012. E-Navigation for Inland Waterways. Terms of Reference. InCom WG 156.

Permanent International Association of Navigation (PIANC). 2014. Report no 121-2014. Harbour approach channels design guidelines.

Permanent International Association of Navigation (PIANC). 2015.What PIANC stands for. Available from internet: http://www.pianc.org/ Accessed: 14/08/2015

Port of Hamburg. 2013. Port of Hamburg Handbook 2013. 156 pp. Available from internet: http://www.hafenhamburg.net/hhm/hafenhamburghandbuch2013.pdf Accessed: 10/02/2017.

Port of Antwerp. 2015. Deepening of the Scheldt: new regulations for upstream and downstream navigation. Available from internet: http://www. portofantwerp.com/en/deepening-scheldt-newregulations-upstream-and-downstream-navigation Accessed: 16/07/2015.

Port of Hamburg. 2015. The River Elbe within the tides. Available from internet: http://www.hafen-hamburg. de/en/the-river-elbe Accessed: 14/07/2015.

River Information Service (RIS). Available from internet: http://www.ris.eu/ Accessed: 17/11/2016.

Suez Canal Authority. 2015. Available from internet: http://www.suezcanal.gov.eg/ Accessed: 29/07/2015.
Swedish Transport Agency. 2015. Transport Styrelsen. Regulations. Available from internet: https://www. transportstyrelsen.se/en/Shipping/EnvironmentalProtection/Regulations/ Accessed: 29/07/2015.

Tidal River Development (TIDE). 2011. Comparison Hydrodynamics and Salinity of Tide Estuaries: Elbe, Humber, Scheldt and Weser. Deltares. Available from internet: http://www.tide-toolbox.eu/pdf/reports/ Comparison_of_Hydrodynamics_and_Salinity_of TIDE_Estuaries.pdf

Tidal River Development (TIDE). 2012. Work package 5 “Measures". Dredging and Disposal Strategies. River Elbe-HPA/WSV. Available from internet: http://www. tide-project.eu/downloads/Dredging_strategies_Elbe_ estuary.pdf

Tidal River Development (TIDE). 2013. Work package 5 "Measures". Dredging and Disposal Strategies. Schelde estuary-MOW. Available from internet: http://www. tide-project.eu/index.php5? $\mathrm{cmd}=$ download\&subcmd $=$ downloads/Dredging_strategies_Scheldt_estuary.pdf

Tozer, D.; Penfold, A. 2001. Ultra Large Container Ships (ULCS). Designing to the limit of current and projected terminal infrastructure capabilities. Lloyd's Register of Shipping. Available from internet: http://www.antiport. de/doku/gutachten/ulcs.pdf Accessed: 29/07/2015.

Vivas Agüero, P. 1999. Globalización de la Economía y/o mundialización del capital./1999. Globalization of the Economy and / or globalization of capital/Edit. Universidad Nacional Mayor de San Marcos. Available from internet: http:// sisbib.unmsm.edu.pe/bibvirtualdata/publicaciones/ economia/11/a06.pdf

World Energy Conference. 1986. Energy. 2nd Edit. Pergamon Press. London. 315 p. 